\title{
Recommendations on screening for asymptomatic bacteriuria in pregnancy
}

\author{
Ainsley Moore MD MSc, Marion Doull PhD, Roland Grad MDCM MSc, Stéphane Groulx MD, Kevin Pottie BSc MD, \\ Marcello Tonelli MD SM, Susan Courage RN BScN, Alejandra Jaramillo Garcia MSc, Brett D. Thombs PhD; for \\ the Canadian Task Force on Preventive Health Care
}

Cite as: CMAJ 2018 July 9;190:E823-30. doi: 10.1503/cmaj.171325

This guideline is available in French at www.cmaj.ca/lookup/suppl/doi:10.1503/cmaj.171325/-/DC1

CMAJ Podcasts: author interview at https://soundcloud.com/cmajpodcasts/171325-guide

$\mathbf{T}$ his guideline from the Canadian Task Force on Preventive Health Care focuses on screening for asymptomatic bacteriuria in pregnancy and re-examines the evidence supporting this routine practice in prenatal care.

Asymptomatic bacteriuria is defined as a quantitative count of $>100 \times 10^{6}$ colony-forming units of bacteria per litre (CFU/L) of urine without specific symptoms of a urinary tract infection. ${ }^{1}$ Women with diabetes, recurrent urinary tract infections, polycystic kidneys, other congenital renal anomalies and sickle cell disease are at higher risk for asymptomatic bacteriuria and associated complications in pregnancy. ${ }^{1-3}$ Prevalence of asymptomatic bacteriuria has been estimated to be $2 \%-10 \%$ in premenopausal ambulatory women, ${ }^{3}$ although the task force did not identify published rates of asymptomatic bacteriuria during pregnancy in Canada.

Depending on the setting and date of the report, there is considerable variation in the reported risk of pyelonephritis associated with untreated asymptomatic bacteriuria in pregnancy. ${ }^{4-7}$ Pyelonephritis has been associated with maternal septicemia, renal dysfunction and anemia, ${ }^{8}$ as well as adverse fetal outcomes, such as low birth weight and preterm birth. ${ }^{3,9}$ Conversely, a recent study found asymptomatic bacteriuria was not associated with preterm birth. ${ }^{4}$ Hence, the relationship between asymptomatic bacteriuria and pregnancy complications is uncertain.

Screening for asymptomatic bacteriuria is done with the intention to treat with antibiotics when bacteriuria is identified. A screening guideline for asymptomatic bacteriuria must consider both potential benefits and possible harms of antibiotic treatment in pregnancy. Randomized controlled trials (RCTs) of antibiotic treatment for asymptomatic bacteriuria in pregnancy, however, have been criticized for poorly reporting harms of antibiotics and for other sources of bias. ${ }^{1}$

Current Canadian practice is to screen for asymptomatic bacteriuria in the first trimester of pregnancy, with antibiotic treatment for positive screens. In women with a history of recurrent urinary tract infections, the Society of Obstetricians and Gynae-

\section{KEY POINTS}

- Systematic reviews on screening and treating asymptomatic bacteriuria in pregnancy found very low-quality evidence for a modest reduction in pyelonephritis among pregnant women and the number of low-birth-weight infants.

- Only scant and very low-quality evidence was available to infer harms associated with screening and treatment of asymptomatic bacteriuria in pregnancy.

- Patient values and preferences regarding screening for asymptomatic bacteriuria are variable and influenced by individual perspectives regarding the small potential benefit of antibiotic use, as well as potential harms associated with antibiotic use in pregnancy.

- A weak recommendation in favour of screening is warranted given the small but uncertain benefit of screening for asymptomatic bacteriuria, variation in women's values and preferences, and the judgment that harms associated with this long-standing practice in Canada are likely minimal.

- Some women who are not at increased risk of urinary tract infections in pregnancy and are more concerned with potential harms of antibiotics may choose not to be screened for asymptomatic bacteriuria; women at increased risk of urinary tract infections in pregnancy should follow guidance for higherrisk populations.

cologists of Canada recommends screening for asymptomatic bacteriuria in each trimester. ${ }^{10}$

Screening for asymptomatic bacteriuria is a part of routine prenatal care in Canada. In 1994, the Canadian Task Force on the Periodic Health Examination concluded that there was good evidence to support a recommendation in favour of screening for asymptomatic bacteriuria early in pregnancy (12-16 wk) using urine culture. ${ }^{11}$ The current task force saw the need for an updated guideline that considers evidence on the potential harms and benefits of screening for asymptomatic bacteriuria in pregnancy and that also considers women's values and preferences regarding screening and resulting outcomes. 


\section{Scope}

This guideline provides patients, clinicians and policy-makers with guidance on screening for asymptomatic bacteriuria in pregnancy. It focuses on women who are not at increased risk for asymptomatic bacteriuria. Women with diabetes, recurrent urinary tract infection, polycystic kidneys, other congenital renal anomalies or sickle cell disease should follow guidance for higher-risk groups.

\section{Methods}

The task force is an independent panel of clinicians and methodologists that makes recommendations on primary and secondary prevention in primary care (www.canadiantaskforce.ca). This document was developed by a working group of five task force members with scientific support from the Public Health Agency of Canada. The recommendations were informed by a systematic review with three key questions ${ }^{12}$ and patient engagement activities with women that addressed specific aspects of the guideline's development (analytical framework, Appendix 1, available at www.cmaj.ca/lookup/suppl/doi:10.1503/cmaj.171325/-/DC2).

The Evidence Review and Synthesis Centre conducted the systematic reviews at the University of Alberta between June and October 2016, and prepublication search updates in September and October 2017. The systematic review was carried out according to a registered protocol (PROSPERO: CRD42016045263)..$^{13}$ For review questions on screening effectiveness, values and preferences, and treatment effectiveness, the review centre conducted peer-reviewed database searches (from inception to September 2017) in MEDLINE, Embase, CINAHL, PubMed, the Cochrane Library and PsycINFO. PsycINFO was included only in the systematic review of values and preferences. Screening and treatment reviews excluded studies that focused on women at higher than average risk for bacteriuria, or who had recurrent urinary tract infections, or had symptoms of a urinary tract infection.

The protocol, ${ }^{13}$ systematic review ${ }^{12}$ and draft guideline were externally reviewed by content experts and organizational stakeholders (see Acknowledgements). Clinical and content experts engage with task force working group members to help them address technical issues and understand important clinical issues, by participating in working group meetings, by reviewing key supporting documents for accuracy and by reviewing the final guideline. Clinical and content experts do not have input into task force recommendations and do not vote on recommendations.

The task force engaged patients in the development of the guideline, in two phases that were conducted by the Knowledge Translation group at St. Michael's Hospital, Toronto. For both phases, 34 women (17 per phase) who were of childbearing age or pregnant and not at increased risk for asymptomatic bacteriuria were recruited through public advertisements and via stakeholder outreach.

During phase 1 , online surveys and telephone focus groups were used to ask the women $(n=17)$ to rate potential health outcomes as critical, important, or not important, and to discuss how their consideration of these outcomes would influence their decision to be screened. This information was used to formulate key questions for the systematic review.

In the second stage, the women $(n=17)$ were provided with synthesized evidence from the systematic reviews through online surveys and telephone focus groups and asked to consider how they valued the potential benefits and harms of asymptomatic bacteriuria screening in light of the evidence. ${ }^{14}$ Results from phase 2 were compared with phase 1 to determine whether the women's valuation of outcomes and decisions to be screened were different when evidence on the likelihood of experiencing those outcomes was provided. Only outcomes that patients and task force members rated as critical or important were included in the systematic reviews.

Final outcomes for screening and treatment included possible benefits: reductions in incidence of maternal mortality, maternal sepsis, pyelonephritis, perinatal mortality ( $\geq 20$ weeks of gestation), spontaneous abortion (< 20 weeks of gestation), neonatal sepsis, preterm delivery ( $<37$ weeks of gestation) and low birth weight ( $\leq 2500 \mathrm{~g}$ ); and possible harms associated with antibiotic use: nonserious and serious adverse events (including fetal anomalies).

The task force used the Grading of Recommendations, Assessment, Development and Evaluation (GRADE) approach to determine quality of evidence and strength of recommendations (Box 1). ${ }^{15}$ Appendix 2 (available at www.cmaj.ca/lookup/suppl/doi: 10.1503/cmaj.171325/-/DC2) provides the GRADE evidence-todecision framework for the recommendations. The recommendation was reviewed and approved by the entire task force.

\section{Management of competing interests}

Funding for the Canadian Task Force on Preventive Health Care is provided by the Public Health Agency of Canada. The views of the funding body have not influenced the content of the guideline. All task force members are required to disclose financial and nonfinancial conflicts of interest. These conflict of interest statements are made available publicly on the task force website. All task force members declared that they had no conflicts of interest for this guideline. Clinical and content experts are required to disclose any conflicts of interest at the outset of their participation and annually thereafter. One content expert declared a conflict in relation to research that was partially supported by industry funds. As per the procedure manual, the task force office reviewed this declaration. It was determined that the declared conflict was unrelated to the present guideline and would not be expected to affect the transparency, integrity and acceptability of the guideline. Content experts do not participate in discussions on recommendations and do not vote on recommendations.

\section{Recommendation}

We recommend screening pregnant women once during the first trimester with urine culture for asymptomatic bacteriuria (weak recommendation; very low-quality evidence).

This recommendation applies to pregnant women who are not experiencing symptoms of a urinary tract infection and are not at increased risk for asymptomatic bacteriuria. 


\section{Box 1: Grading of recommendations}

Recommendations are graded according to the Grading of Recommendations Assessment, Development and Evaluation system (GRADE). ${ }^{15}$ GRADE offers two strengths of recommendation: strong and weak. The strength of recommendations is based on the balance between desirable and undesirable outcomes; the confidence in the magnitude of the estimates of effect of the intervention on outcomes; the confidence in values and preferences and their variability; and whether the intervention represents a wise use of resources.

Strong recommendations are those for which the task force is confident that the desirable effects of an intervention outweigh its undesirable effects (strong recommendation for an intervention) or that the undesirable effects of an intervention outweigh its desirable effects (strong recommendation against an intervention). A strong recommendation implies that most individuals will be best served by the recommended course of action and that the recommendation can be adopted in practice or as policy in most situations.

Strong recommendations are normally based on high-quality evidence (i.e., high confidence in the estimate of the effect of an intervention). Strong recommendations may recommend in favour of an intervention (when there is high confidence of benefit) or against an intervention (when there is high confidence of harm). However, there are five circumstances in which the task force may consider a strong recommendation based on low- or very lowquality evidence: ${ }^{15}$

- When low-quality evidence suggests benefit in a life-threatening situation (evidence regarding harms can be low or high).

- When low-quality evidence suggests benefit and high-quality evidence suggests harm or a very high cost.

- When low-quality evidence suggests equivalence of two alternatives, but high-quality evidence of less harm for one of the competing alternatives.

- When high-quality evidence suggests equivalence of two alternatives and low-quality evidence suggests harm in one alternative.

- When high-quality evidence suggests modest benefits and low- or very low-quality evidence suggests possibility of catastrophic harm.

Weak recommendations are those for which the desirable effects probably outweigh the undesirable effects (weak recommendation for an intervention) or undesirable effects probably outweigh the desirable effects (weak recommendation against an intervention) but appreciable uncertainty exists. Weak recommendations result when the balance between desirable and undesirable effects is small, the quality of evidence is lower, or there is more variability in the values and preferences of patients. Cases in which the balance of cost and benefits is ambiguous, key stakeholders differ about the acceptability or feasibility of the implementation, and the effects on health equity are unclear are likely to result in a weak recommendation. A weak recommendation implies that most people would want the recommended course of action, but that many would not. For clinicians, this means they must recognize that different choices will be appropriate for each individual, and that they must help each person arrive at a management decision consistent with his or her values and preferences. Policy-making will require substantial debate and involvement of various stakeholders.

Evidence is graded as high, moderate, low or very low quality, based on how likely further research is to change the task force's confidence in the estimate of effect.

\section{Screening}

The systematic review on outcomes of screening for asymptomatic bacteriuria did not identify any RCTs that compared the effects of screening with those of no screening. It did identify four observational studies, with a total of 7611 women, that compared screening to no screening. ${ }^{16-19}$ All four studies used nonconcurrent cohort designs to evaluate outcomes before and after screening practices began. Three studies examined outcomes of implementing universal screening versus no screening in Spain, ${ }^{16}$ Turkey ${ }^{17}$ and France. ${ }^{18}$ The fourth study, conducted in the United States, examined the effectiveness of screening at every prenatal visit versus at the first prenatal visit only. ${ }^{19}$

Meta-analysis ${ }^{12}$ of the three cohort studies $(n=5659)$ that compared screening to no screening ${ }^{16-18}$ found very low-quality evidence of an absolute risk reduction (ARR) for pyelonephritis of 13 fewer women per 1000 screened (ARR 1.3\%, 95\% confidence interval $[\mathrm{Cl}] 8$ to 16 fewer). The number needed to screen to prevent one case of pyelonephritis was 77 (95\% Cl 65 to 121) (Table 1).

Data for other screening outcomes, including harms, were also of very low quality. There were few events, and effect estimates were highly imprecise (Table 1$)$. In two studies $(n=724)$, women screened for asymptomatic bacteriuria had four more cases of perinatal mortality per 1000 women screened (absolute risk increase [ARI] $0.4 \%, 95 \% \mathrm{Cl} 19$ fewer to 1000 more). ${ }^{17,18}$ In the same two studies $(n=722)$, there were 102 more preterm deliveries per 1000 women screened (ARI 10.2\%, 95\% Cl 9 fewer to 1000 more). ${ }^{17,18}$ Based on data from one study $(n=372)$, there were five more babies with fetal anomalies per 1000 women screened (ARI $0.5 \%, 95 \% \mathrm{Cl} 8$ fewer to 85 more) and two fewer spontaneous abortions per 1000 women screened ( $n=370$, ARR $0.2 \%, 95 \% \mathrm{Cl}$ 32 fewer to 70 more)..$^{17}$

One study ( $n=1952)$ compared the incidence of pyelonephritis among women who were screened using urine dipstick testing at every prenatal visit compared with women who were screened at the first prenatal visit only. ${ }^{19}$ This study found zero fewer cases of pyelonephritis per 1000 women who were screened at all visits compared with women screened at the first visit only (95\% Cl 3 fewer to 13 more). ${ }^{19}$ Risk of preterm delivery was higher in the group screened at all visits versus those screened only at the first visit (ARI 28 more women per 1000 [2.8\%], 95\% Cl 5 more to 60 more).${ }^{18}$ Evidence was rated as very low quality for both outcomes.

\section{Treatment}

Linked evidence on screening effectiveness was provided from an update of a 2015 Cochrane review, ${ }^{1}$ which compared antibiotic treatment with no treatment or placebo among pregnant women with asymptomatic bacteriuria. In total, there were 15 eligible studies, including one new study identified during the search update. ${ }^{4}$ Eleven studies were RCTs, and four were nonrandomized controlled clinical trials. All but one, in Jamaica, ${ }^{20}$ were conducted in high-income countries, including the US,, $21-24$ United Kingdom, ${ }^{25-27}$ Ireland, ${ }^{28}$ Australia, ${ }^{29-31}$ Denmark ${ }^{32}$ and the Netherlands. ${ }^{4}$ Studies varied in terms of testing protocols (e.g., timing during pregnancy, number of confirmatory urine 
samples), treatment (e.g., dose, type of antibiotic) and follow-up periods.

Meta-analysis of 12 studies ( $n=2017$ ), including nine RCTs and three nonrandomized controlled clinical trials, found lowquality evidence for a statistically and clinically significant reduction in the rate of pyelonephritis among pregnant women with asymptomatic bacteriuria who were treated, compared with those not treated. The ARR was 176 fewer cases of pyelonephritis per 1000 among women with asymptomatic bacteriuria who were treated (ARR $17.6 \%, 95 \% \mathrm{Cl} 137$ fewer to 202 fewer, number needed to treat 6). ${ }^{12}$ Across seven studies ( $n=1522$ ), there was also low-quality evidence for a statistically significant reduction of 44 fewer low-birth-weight infants born per 1000 women with asymptomatic bacteriuria who were treated (ARR 4.4\%, 95\% Cl 12 fewer to 65 fewer).
Very low-quality evidence was found for other treatment outcomes of interest, including harms of antibiotic treatment. No statistically significant or clinically important differences were found for perinatal mortality, spontaneous abortion, neonatal sepsis, preterm delivery or fetal anomalies (Table 2).

\section{Patient values and preferences}

In total, 34 women from across Canada (ages 21-41), of whom 14 were pregnant, participated in online surveys and telephone focus groups across the two phases of engagement work. Women rated all the outcomes examined in the systematic reviews on screening effectiveness as critical, except for pyelonephritis, which they rated as important. The initial focus groups, before evidence synthesis, found that women weighed potential screening benefits as more important than possible harms of screening

Table 1: Outcome summary of screening versus no screening for asymptomatic bacteriuria among pregnant women

\begin{tabular}{|c|c|c|c|c|c|c|c|c|}
\hline Outcome & $\begin{array}{l}\text { No. of } \\
\text { studies }\end{array}$ & $\begin{array}{c}\text { Women } \\
\text { screened } \\
(n / N)\end{array}$ & $\begin{array}{l}\text { Women not } \\
\text { screened } \\
(n / N)\end{array}$ & $\begin{array}{c}\mathbf{R R} \\
(95 \% \mathrm{CI})\end{array}$ & $\begin{array}{l}\text { Absolute difference } \\
\text { per } 1000(95 \% \mathrm{Cl})\end{array}$ & ARR, $\%$ & ARI, $\%$ & $\begin{array}{l}\text { Quality of } \\
\text { evidence }\end{array}$ \\
\hline Pyelonephritis & $3^{16-18}$ & $10 / 2008$ & $67 / 3651$ & $\begin{array}{c}0.28 \\
(0.15 \text { to } 0.54)\end{array}$ & $\begin{array}{c}13 \text { fewer } \\
\text { (8 fewer to } 16 \text { fewer) }\end{array}$ & 1.3 & - & Very low \\
\hline $\begin{array}{l}\text { Perinatal } \\
\text { mortality }\end{array}$ & $2^{17,18}$ & $6 / 349$ & $7 / 375$ & $\begin{array}{c}1.21 \\
\text { (0.01 to } 102.93)\end{array}$ & $\begin{array}{c}4 \text { more } \\
\text { (19 fewer to } 1000 \text { more) }\end{array}$ & - & 0.4 & Very low \\
\hline $\begin{array}{l}\text { Spontaneous } \\
\text { abortion }\end{array}$ & $1^{17}$ & $9 / 170$ & $11 / 200$ & $\begin{array}{c}0.96 \\
\text { (0.41 to } 2.27)\end{array}$ & $\begin{array}{c}2 \text { fewer } \\
\text { (32 fewer to } 70 \text { more) }\end{array}$ & 0.2 & & Very low \\
\hline $\begin{array}{l}\text { Preterm } \\
\text { delivery }\end{array}$ & $2^{17,18}$ & $33 / 347$ & $5 / 375$ & $\begin{array}{c}8.70 \\
\text { (0.32 to } 240.07)\end{array}$ & $\begin{array}{c}102 \text { more } \\
\text { (9 fewer to } 1000 \text { more) }\end{array}$ & - & 10.2 & Very low \\
\hline Fetal anomalies & $1^{17}$ & $3 / 186$ & $2 / 186$ & $\begin{array}{c}1.50 \\
(0.25 \text { to } 8.87)\end{array}$ & $\begin{array}{c}5 \text { more } \\
\text { (8 fewer to } 85 \text { more) }\end{array}$ & - & 0.5 & Very low \\
\hline
\end{tabular}

Note: $\mathrm{ARI}=$ absolute risk increase, $\mathrm{ARR}=$ absolute risk reduction, $\mathrm{Cl}=$ confidence interval, $\mathrm{RR}=$ risk ratio .

Table 2: Outcome summary treatment $v$. no treatment for asymptomatic bacteriuria among pregnant women

\begin{tabular}{|c|c|c|c|c|c|c|c|}
\hline Outcome & No. of studies & $\begin{array}{c}\text { Women } \\
\text { treated } \\
(n / N)\end{array}$ & $\begin{array}{c}\text { Women } \\
\text { not treated } \\
(n / N)\end{array}$ & $\begin{array}{c}\mathbf{R R} \\
(95 \% \mathrm{Cl})\end{array}$ & $\begin{array}{l}\text { Absolute difference } \\
\text { per } 1000(95 \% \mathrm{CI})\end{array}$ & ARR, \% & $\begin{array}{l}\text { Quality of } \\
\text { evidence }\end{array}$ \\
\hline Pyelonephritis & $12^{4,6,20,22-29,30}$ & $55 / 1023$ & $198 / 994$ & $\begin{array}{c}0.24 \\
(0.13 \text { to } 0.41)\end{array}$ & $\begin{array}{c}176 \text { fewer } \\
\text { (137 fewer to } 202 \text { fewer) }\end{array}$ & 17.6 & Low \\
\hline Low birth weight & $7^{4,6,622,25,27,29,31}$ & $64 / 769$ & $100 / 753$ & $\begin{array}{c}0.63 \\
(0.45 \text { to } 0.90)\end{array}$ & $\begin{array}{c}44 \text { fewer } \\
\text { (12 fewer to } 65 \text { fewer) }\end{array}$ & 4.4 & Low \\
\hline $\begin{array}{l}\text { Perinatal } \\
\text { mortality }\end{array}$ & $6^{4,6,22,25,29,31}$ & $16 / 529$ & $21 / 575$ & $\begin{array}{c}0.96 \\
(0.27 \text { to } 3.39)\end{array}$ & $\begin{array}{c}2 \text { fewer } \\
\text { (29 fewer to } 97 \text { more) }\end{array}$ & 0.2 & Very low \\
\hline $\begin{array}{l}\text { Spontaneous } \\
\text { abortion }\end{array}$ & $2^{30,31}$ & $4 / 222$ & $6 / 157$ & $\begin{array}{c}0.60 \\
(0.11 \text { to } 3.10)\end{array}$ & $\begin{array}{c}13 \text { fewer } \\
\text { (30 fewer to } 70 \text { more) }\end{array}$ & 1.3 & Very low \\
\hline Neonatal sepsis & $2^{4,32}$ & $0 / 77$ & $2 / 77$ & $\begin{array}{c}0.22 \\
\text { (0.01 to } 4.54)\end{array}$ & $\begin{array}{c}17 \text { fewer } \\
\text { (22 fewer to } 79 \text { more) }\end{array}$ & 1.7 & Very low \\
\hline Preterm delivery & $4^{4,30-32}$ & $34 / 299$ & $39 / 234$ & $\begin{array}{c}0.57 \\
(0.21 \text { to } 1.56)\end{array}$ & $\begin{array}{c}68 \text { fewer } \\
\text { (125 fewer to } 88 \text { more) }\end{array}$ & 6.8 & Very low \\
\hline Fetal anomalies & $4^{4,22,25,30}$ & $4 / 425$ & $10 / 396$ & $\begin{array}{c}0.49 \\
(0.17 \text { to } 1.43)\end{array}$ & $\begin{array}{c}9 \text { fewer } \\
\text { (15 fewer to } 8 \text { more) }\end{array}$ & 0.9 & Very low \\
\hline
\end{tabular}

Note: $A R R=$ absolute risk reduction, $\mathrm{Cl}=$ confidence interval, $\mathrm{RR}=$ risk ratio. 
for asymptomatic bacteriuria, in part because the screening test was not in itself seen as harmful.

In the second phase of engagement, women were presented with synthesized evidence of screening and treatment effectiveness and were asked to consider whether they would undergo screening in light of this evidence. Women again did not see screening as harmful, but uncertainty regarding antibiotic use was a concern for some women. Women in the focus groups indicated a preference for screening, but some said they would reassess treatment decisions once they knew test results. Consequently, important variation in values and preferences was identified when women considered the evidence on overall benefits and harms of screening and subsequent treatment. Past experience with antibiotic use and pregnancy complications, as well as unknown harms to babies and women themselves, influenced their preferences both in favour and against treatment of asymptomatic bacteriuria in pregnancy. ${ }^{14}$

The systematic review did not find any studies that provided direct evidence on how women weigh the benefits versus harms of screening for asymptomatic bacteriuria, but did find indirect evidence (eight cross-sectional studies) on women's opinions related to use of antibiotics in pregnancy. ${ }^{12}$ Similarly to the findings from the focus groups, these studies reached conflicting conclusions regarding antibiotic use during pregnancy, although there appears to be greater concern among pregnant women about risks of teratogenesis compared with risks to themselves.

\section{Resource use}

Current cost-effectiveness studies were not available to inform resource considerations. Lack of data on prevalence of asymptomatic bacteriuria and uncertain estimates of risk reduction limit capacity for accurately estimating cost-effectiveness.

\section{Feasibility, acceptability, cost and equity}

Urine culture, the gold standard for screening for asymptomatic bacteriuria, is part of standard prenatal care in Canada, and the task force judged it to be feasible and acceptable to clinicians and women. Task force members considered the cost of screening for asymptomatic bacteriuria to be relatively low compared with the overall costs of prenatal care in Canada. All systematic reviews informing this guideline were designed to conduct subgroup analyses to identify vulnerable groups. However, no data were available to inform specific recommendations or considerations for vulnerable groups.

\section{Rationale}

Overall, very low-quality evidence was found for the benefits and harms of screening for asymptomatic bacteriuria in pregnancy. Linked evidence on screening that considers the effectiveness of treating asymptomatic bacteriuria identified by screening was found. Low-quality evidence suggested that treatment modestly reduces the incidence of pyelonephritis and the number of lowbirth-weight infants. It is a long-standing practice in Canada to provide routine screening and treatment of asymptomatic bacteriuria in pregnancy, and this may contribute to the apparently low prevalence of pyelonephritis among pregnant women in
Canada. In addition, the resources required to provide such screening are modest. Therefore, in the judgment of the task force, the potential benefits of screening outweigh possible harms, and a weak recommendation in favour of screening is warranted. This recommendation places a relatively higher priority on the small but uncertain benefit of screening for asymptomatic bacteriuria and a relatively lower priority on the lack of evidence regarding serious harms associated with antibiotic use for pregnant women and their babies.

The recommendation is weak because of uncertainty regarding the benefits of screening, as well as the various preferences of women with respect to antibiotic treatment in pregnancy. Women who are interested in small, uncertain, potential reductions in risk of pyelonephritis and low birth weight will be more likely to choose screening for asymptomatic bacteriuria. However, women who are more concerned with potential harms of antibiotics may be more likely to choose not to be screened; in such circumstances, there is potential value for discussion between clinicians and patients in order to reach evidenceinformed decisions that are congruent with patient values and preferences.

\section{Considerations for implementation}

The task force advises that screening should be conducted once in the first trimester with a urine culture, or at the first prenatal visit, if this visit occurs later in pregnancy. There is no evidence for an optimal screening time in pregnancy. For ease of implementation, this recommendation advises first-trimester screening, recognizing that not all women will present for prenatal care during the first trimester, and that screening may occur after the first trimester.

This recommendation pertains to women who are not at increased risk for asymptomatic bacteriuria and who are not experiencing symptoms of a urinary tract infection. Women with diabetes, recurrent urinary tract infections, polycystic kidneys, other congenital renal anomalies or sickle cell disease are not included in the recommendation, and their care should follow guidance for higher-risk groups. A history of recurrent urinary tract infection is defined as two uncomplicated infections in the past six months, or three positive cultures in the past 12 months. ${ }^{10}$

When urine cultures are not available, clinicians should be aware that alternatives have sufficient specificity but poor sensitivity for asymptomatic bacteriuria (e.g., 99\% v. 55\%, respectively, for urine dipstick) ${ }^{33}$ and thus fail to detect a substantial number of cases. ${ }^{34}$ The quality of evidence considering screening with a single urine culture compared with two urine cultures (for confirmation) was too poor to provide guidance on the appropriate strategy. All the evidence supporting a reduction in pyelonephritis from treatment studies included a test for cure. Clinicians should follow relevant treatment guidance for women with a positive screen for asymptomatic bacteriuria. ${ }^{10}$

\section{Monitoring and evaluation}

This is a weak recommendation, which recognizes that some women will choose to undergo screening, whereas others may 
Table 3: National and international recommendations on screening for asymptomatic bacteriuria in pregnancy

Guideline group

Canadian Task Force on

Preventive Health Care

(current guideline, 2018)

Canadian Task Force on the Periodic Health Examination ${ }^{11}$

United States Preventive Services Task Force ${ }^{34}$

Scottish Intercollegiate Guidelines Network, Scotland ${ }^{35}$

The National Institute for Health and Care Excellence, $\mathrm{UK}^{36}$

The American Academy of Family Physicians ${ }^{37}$

The Infectious Disease Society of America ${ }^{38}$

\section{Recommendation}

We recommend screening pregnant women once during the first trimester with urine culture for asymptomatic bacteriuria (weak recommendation; very low-quality evidence).

This recommendation applies to pregnant women who are not experiencing symptoms of a urinary tract infection and are not at increased risk for asymptomatic bacteriuria.

Good evidence to include screening once by culture method for asymptomatic bacteriuria at 12-16 weeks of pregnancy.

The United States Preventive Services Task Force recommends screening for asymptomatic bacteriuria with urine culture for pregnant women at 12 to 16 weeks' gestation or at their first prenatal visit, if later. (Grade A: The United States Preventive Services Task Force recommends the service. There is high certainty that the net benefit is substantial.)

Standard quantitative urine culture should be performed routinely at first antenatal visit (Grade A). Confirm the presence of bacteriuria in the urine with a second urine culture (Grade A).

Do not use dipstick testing to screen for bacterial urinary tract infection at the first or subsequent visits (Grade A).

Treat asymptomatic bacteriuria detected during pregnancy with an antibiotic (Grade A).

Women with bacteriuria that is confirmed by a second urine culture should be treated and have repeat urine culture at each antenatal visit until delivery (Grade C).

Women should be offered routine screening for asymptomatic bacteriuria by midstream urine culture early in pregnancy. Identification and treatment of asymptomatic bacteriuria reduce the risk of pyelonephritis.

Pregnant women should be screened for asymptomatic bacteriuria in the first trimester of pregnancy (Grade A: consistent, good-quality patient-oriented evidence).

Pregnant women who have asymptomatic bacteriuria should be treated with antimicrobial therapy for 3 to 7 days (Grade B: inconsistent or limited-quality patient-oriented evidence).

The diagnosis of asymptomatic bacteriuria should be based on results of culture of a urine specimen collected in a manner that minimizes contamination (Grade A-II).

Pregnant women should be screened for bacteriuria by urine culture at least once in early pregnancy, and they should be treated if the results are positive (Grade A-I).

Periodic screening for recurrent bacteriuria should be undertaken after therapy (Grade A-III).

No recommendation can be made for or against repeated screening of women who are culture negative in later pregnancy. not. Therefore, clinician awareness of this recommendation is a performance measure for this guideline.

\section{Other guidelines}

Although this recommendation aligns with guidelines from other international organizations, the task force places lower certainty on the evidence than other groups (Table 3). ${ }^{10,34-38}$ This uncertainty contributes to a weak recommendation in favour of screening.

For example, the United States Preventive Services Task Force provides a grade A-level recommendation that advises screening all pregnant women at 12 to 16 weeks (or at first prenatal visit), based on "high certainty for a substantial net benefit" of treatment with antibiotics to reduce substantially the incidence of symptomatic maternal urinary tract infections. ${ }^{34}$

\section{Gaps in knowledge}

High-quality trials for screening and treatment of asymptomatic bacteriuria conducted in the current era of modern obstetrics were not available to inform this recommendation. It is possible that risks associated with asymptomatic bacteriuria may have decreased since the publication of studies informing this guideline. This, coupled with advances in prenatal care, may reduce the absolute benefits of screening. Studies evaluating rates of asymptomatic bacteriuria among pregnant women in Canada are required to inform accurate baseline risk. More information is also needed on independent factors that place some groups of women at clinically important risk for asymptomatic bacteriuria.

The studies included in the evidence review used various algorithms to confirm a positive asymptomatic bacteriuria diagnosis; further research is required to confirm best practice for diagnosis, such as the number of repeat urine cultures. Preference-based studies on how Canadian women weigh asymptomatic bacteriuria screening outcomes would be clinically useful to understand the proportion of women who choose and do not choose screening. A pragmatic trial design comparing treatment-based versus tolerant screening (e.g., those without a preference toward or against screening are randomized, while others self-select an intervention arm) that includes data on all critical outcomes is needed to determine more contemporary estimates of effectiveness. We are aware that one such trial has been deemed feasible and is underway for risk-based versus routine breast cancer screening in the US. ${ }^{39}$ 


\section{Conclusion}

Screening with urine culture during pregnancy and treatment of asymptomatic bacteriuria, defined as $>100 \times 10^{6} \mathrm{CFU} / \mathrm{L}$ of urine without specific symptoms of a urinary tract infection, is a longstanding practice in Canada that may provide a modest reduction in pyelonephritis for women and may reduce the number of low-birth-weight infants. Serious harms from antibiotics, although possible, were not reported in our systematic reviews.

This weak recommendation in favour of screening for asymptomatic bacteriuria in pregnancy recognizes that some women who are not at increased risk of asymptomatic bacteriuria in pregnancy and are more concerned with potential harms of antibiotics may choose not to be screened or treated for asymptomatic bacteriuria. In such circumstances, there is potential value for discussion between clinicians and patients in order to reach evidence-informed and values-based decisions. This guideline does not apply to women at increased risk of asymptomatic bacteriuria in pregnancy, who should follow guidance for higher-risk populations.

\section{References}

1. Smaill FM, Vazquez JC. Antibiotics for asymptomatic bacteriuria in pregnancy. Cochrane Database Syst Rev 2015;(8):CD000490.

2. Glaser AP, Schaeffer AJ. Urinary tract infection and bacteriuria in pregnancy. Urol Clin North Am 2015;42:547-60.

3. Schnarr J, Smaill F. Asymptomatic bacteriuria and symptomatic urinary tract infections in pregnancy. Eur J Clin Invest 2008;38(Suppl 2):50-7.

4. Kazemier BM, Koningstein FN, Schneeberger C, et al. Maternal and neonatal consequences of treated and untreated asymptomatic bacteriuria in pregnancy: a prospective cohort study with an embedded randomised controlled trial. Lancet Infect Dis 2015;15:1324-33.

5. Harris RE. The significance of eradication of bacteriuria during pregnancy. Obstet Gynecol 1979;53:71-3.

6. Kass $E$. The role of asymptomatic bacteriuria in the pathogenesis of pyelonephritis. In: Quinn E, Kass E, editors. Biology of pyelonephritis. Boston: Little Brown and Co.; 1960:399-412.

7. Sweet RL. Bacteriuria and pyelonephritis during pregnancy. Semin Perinatol $1977 ; 1: 25-40$.

8. Wing DA, Fassett MJ, Getahun D. Acute pyelonephritis in pregnancy: an 18-year retrospective analysis. Am J Obstet Gynecol 2014;210:219.e1-6.

9. Ipe DS, Sundac L, Benjamin WH Jr, et al. Asymptomatic bacteriuria: prevalence rates of causal microorganisms, etiology of infection in different patient populations, and recent advances in molecular detection. FEMS Microbiol Lett 2013; 346:1-10.

10. Allen VM, Yudin MH; Infectious Diseases Committee. Management of group B streptococcal bacteriuria in pregnancy. J Obstet Gynaecol Can 2012;34:482-6.

11. Nicolle L. Screening for asymptomatic bacteriuria in pregnancy. In: Canadian guide to clinical preventive health care. Ottawa: Health Canada; 1994:100-6.

12. Wingert A, Pillay J, Featherstone R, et al. Screening for asymptomatic bacteriuria in pregnancy: systematic review and meta-analysis. Edmonton: Evidence Review and Synthesis Centre, University of Alberta; 2017. Available: http://canadiantaskforce .ca/guidelines/published-guidelines/asymptomatic-bacteriuria/ (accessed 2017 Mar. 1)

13. Wingert A, Pillay J, Featherstone R, et al. Screening for asymptomatic bacteriuria in pregnancy: protocol for evidence review. Edmonton; Evidence Review
Synthesis Centre; 2016. Available: http://canadiantaskforce.ca/guidelines/ published-guidelines/asymptomatic-bacteriuria/ (accessed 2016 Dec. 1).

14. Frederickson K, Buckland D, Sayal R, et al. Patient preferences in considering asymptomatic bacteriuria screening and treatment outcomes. Toronto: Knowledge Translation Program Li Ka Shing Knowledge Institute, St. Michael's Hospital; 2017. Available: http://canadiantaskforce.ca/guidelines/published-guidelines/ asymptomatic-bacteriuria/ (accessed 2016 Nov. 29).

15. Schünemann H, Brożek J, Guyatt G, et al., editors. GRADE handbook. GRADE Working Group; 2013. Available: http://gdt.guidelinedevelopment.org/app/handbook/ handbook.html (accessed 2018 Mar. 13).

16. Gratacós E, Torres PJ, Vila J, et al. Screening and treatment of asymptomatic bacteriuria in pregnancy prevent pyelonephritis. J Infect Dis 1994;169:1390-2.

17. Uncu Y, Uncu G, Esmer A, et al. Should asymptomatic bacteriuria be screened in pregnancy? Clin Exp Obstet Gynecol 2002;29:281-5.

18. Gérard J, Blazquez G, Mounac M. Importance of systematic research of urinary infection in pregnant women and the cost of its detection. Proposal for a practical approach [article in French]. J Gynecol Obstet Biol Reprod (Paris) 1983;12:243-51.

19. Rhode MA, Shapiro H, Jones OW III. Indicated vs. routine prenatal urine chemical reagent strip testing. J Reprod Med 2007;52:214-9.

20. Pathak UN, Tang K, Williams LL, et al. Bacteriuria of pregnancy: results of treatment. J Infect Dis 1969;120:91-103.

21. Elder HA, Santamarina BA, Smith SA, et al. Use of sulfasymazine in the treatment of bacteriuria of pregnancy. Antimicrob Agents Chemother (Bethesda) 1966; 6:142-8.

22. Elder HA, Santamarina BA, Smith S, et al. The natural history of asymptomatic bacteriuria during pregnancy: the effect of tetracycline on the clinical course and the outcome of pregnancy. Am J Obstet Gynecol 1971;111:441-62.

23. Gold EM, Traub FB, Daichman I, et al. Asymptomatic bacteriuria during pregnancy. Obstet Gynecol 1966;27:206-9.

24. Mulla N. Bacteriuria in pregnancy. Obstet Gynecol 1960;16:89-92.

25. Little PJ. The incidence of urinary infection in 5000 pregnant women. Lancet 1966;2:925-8.

26. Williams GL, Campbell H, Davies KJ. Urinary concentrating ability in women with asymptomatic bacteriuria in pregnancy. BMJ 1969;3:212-5.

27. Brumfitt W. The effects of bacteriuria in pregnancy on maternal and fetal health. Kidney Int Suppl 1975;4:S113-9.

28. Foley ME, Farquharson R, Stronge JM. Is screening for bacteriuria in pregnancy worthwhile? Br Med J (Clin Res Ed) 1987;295:270.

29. Kincaid-Smith P, Bullen M. Bacteriuria in pregnancy. Lancet 1965;1:395-9.

30. Furness ET, McDonald PJ, Beasley NV. Urinary antiseptics in asymptomatic bacteriuria of pregnancy. N Z Med J 1975;81:417-9.

31. Wren BG. Subclinical renal infection and prematurity. Med J Aust 1969;2:596-600.

32. Thomsen AC, Mørup L, Hansen KB. Antibiotic elimination of group-B streptococci in urine in prevention of preterm labour. Lancet 1987;1:591-3.

33. Rogozińska E, Formina S, Zamora J, et al. Accuracy of onsite tests to detect asymptomatic bacteriuria in aregnancy: a systematic review and meta-analysis. Obstet Gynecol 2016;128:495-503.

34. U.S. Preventive Services Task Force. Screening for asymptomatic bacteriuria in adults: U.S. Preventive Services Task Force reaffirmation recommendation statement. Ann Intern Med 2008;149:43-7.

35. Scottish Intercollegiate Guidelines Network (SIGN). Management of suspected bacterial urinary tract infections in adults. Publication No. 88. Edinburgh, Scotland (UK): SIGN; 2012. Available: http://www.sign.ac.uk/sign-88-management -of-suspected-bacterial-urinary-tract-infection-in-adults.html (accessed 2018 Mar. 13). 
36. Antenatal care for uncomplicated pregnancies. London (UK): National Institute for Health and Care Excellence; March 2008 (updated January 2017). Available: www.nice.org.uk/guidance/cg62 (accessed 2018 Mar. 13).

37. Summary of recommendations for clinical preventive services. Leawood (KS): American Academy of Family Physicians; May 2014. Available: www.cchpsc. org/media/US-Preventative-Task-Force.pdf (accessed 2018 Mar. 13).

38. Nicolle LE, Bradley S, Colgan R, et al.; Infectious Diseases Society of America. American Society of Nephrology; American Geriatric Society. Infectious Diseases
Society of America guidelines for the diagnosis and treatment of asymptomatic bacteriuria in adults. Clin Infect Dis 2005;40:643-54.

39. Rosenberg-Wohl S, Narasimmaraj P, Fiscalini AS, et al. Enabling a paradigm shift: a preference-tolerant RCT of personalized vs. annual screening for breast cancer. J Clin Oncol 34(Suppl) [Epub ahead of print]. doi:10.1200/JCO.2016.34.15_ suppl.e18281.
This article has been peer reviewed.

Authors: Ainsley Moore MD MSc, Marion Doull PhD, Roland Grad MDCM MSc, Stéphane Groulx MD, Kevin Pottie BSc MD, Marcello Tonelli MD SM, Susan Courage RN BScN, Alejandra Jaramillo Garcia MSc, Brett D. Thombs PhD; for the Canadian Task Force on Preventive Health Care

\section{Competing interests: None declared.}

Affiliations: Department of Family Medicine (Moore), McMaster University, Hamilton, Ont.; Public Health Agency of Canada (Doull, Courage, Jaramillo Garcia), Ottawa, Ont.; Department of Family Medicine (Grad), McGill University, Montréal, Que.; Department of Community Health Sciences (Groulx), University of Sherbrooke, Sherbrooke, Que.; Department of Family Medicine (Pottie), University of Ottawa, Ottawa, Ont.; Department of Medicine (Tonelli), University of Calgary, Calgary, Alta.; Lady Davis Institute (Thombs), Jewish General Hospital and McGill University, Montréal, Que.

Guideline Writing Group: Ainsley Moore (voting task force member), Marion Doull (nonvoting science team member), Roland Grad (voting task force member), Stéphane Groulx (voting task force member), Kevin Pottie (voting task force member), Marcello Tonelli (voting task force member), Susan Courage (nonvoting science team member), Alejandra Jaramillo Garcia (nonvoting science team member), Brett D. Thombs (voting task force member).

Contributors: Ainsley Moore, Marion Doull, Roland Grad, Stéphane Groulx, Kevin Pottie, Marcello Tonelli, Susan Courage, Alejandra Jaramillo Garcia and Brett Thombs contributed substantially to the study concept and design, interpretation of the evidence and critical revision of the guideline draft. Marion Doull, Susan Courage and Alejandra Jaramillo
Garcia provided science and logistical support to the writing group. Ainsley Moore, Heather Colquhoun, Roland Grad, Stéphane Groulx, Scott Klarenbach, Eddy Lang, John Leblanc, Gabriela Lewin, Kevin Pottie, Donna Reynolds, Harminder Singh, Guylène Thériault, Brett Thombs, Marcello Tonelli and Brenda Wilson drafted the recommendations. Ainsley Moore and Marion Doull drafted the guideline statement. All authors gave final approval of the version of the guideline to be published and agree to be accountable for all aspects of the work. All collaborating members of the Canadian Task Force on Preventive Health Care (Heather Colquhoun, Scott Klarenbach, Eddy Lang, John Leblanc, Gabriela Lewin, Donna Reynolds, Harminder Singh, Guylène Thériault, Brenda Wilson) also made contributions to the development of the guideline and all gave final approval of the version of the guideline to be published.

Funding: Funding for the Canadian Task Force on Preventive Health Care is provided by the Public Health Agency of Canada. The views of the funding body have not influenced the content of the guideline. The views expressed in this article are those of the task force and do not necessarily represent those of the Public Health Agency of Canada.

Acknowledgements: The authors would like to thank the Alberta Evidence Review and Synthesis Centre team (Aireen Wingert, Jennifer Pillay, Robin Featherstone, Michelle Gates, Meghan Sebastianski, Kassi Shave, Ben Vandermeer, Lisa Hartling) for the evidence review that supported this guideline; Prinon Rahman and Ernesto Delgado of the Global Health and Guidelines Division at the Public Health Agency of Canada, who supported the development of the guideline; and the Knowledge Translation Program, Li Ka Shing Know- ledge Institute, St. Michael's Hospital, for their contributions to patient engagement and knowledge translation work related to this guideline. They would also like to thank Dr. Anne Biringer (Faculty of Family \& Community Medicine, University of Toronto, Toronto, Ont.), Dr. Deborah Money (Faculty of Medicine, University of British Columbia, Vancouver, BC) and Dr. Fiona Smaill (Pathology and Molecular Medicine, McMaster University, Hamilton, Ont.) for assisting as clinical or content experts during the development of this guideline. (Clinical and content experts who have assisted the task force in the guideline process may or may not agree with the task force recommendations.) Additionally, the authors would like to thank peer reviewers and organizational stakeholders who reviewed and provided feedback on the draft guideline, including $\mathrm{Dr}$. Linda Brubaker (Department of Obstetrics, Gynecology and Reproductive Sciences, University of San Diego, San Diego, Calif.), Dr. Venu Jain (Association of Academic Professionals in Obstetrics and Gynaecology), Jennifer Marandola (Canadian Association of Perinatal and Women's Health Nurses), Dr. Lindsay Nicolle (Department of Internal Medicine and Medical Microbiology, Winnipeg, Man.), Dr. Gilles Plourde (Health Canada, Ottawa, Ont.), Dr. Anil Kapoor (Canadian Urological Society), Dr. Peter Daley (Faculty of Medicine, Memorial University, St. John's, NL) and Dr. Barbara Trautner (Baylor College of Medicine, Houston, Tex.). The authors also thank those who contributed comments but did not wish to be acknowledged.

Correspondence to: Canadian Task Force on Preventive Health Care, info@canadiantaskforce.ca 